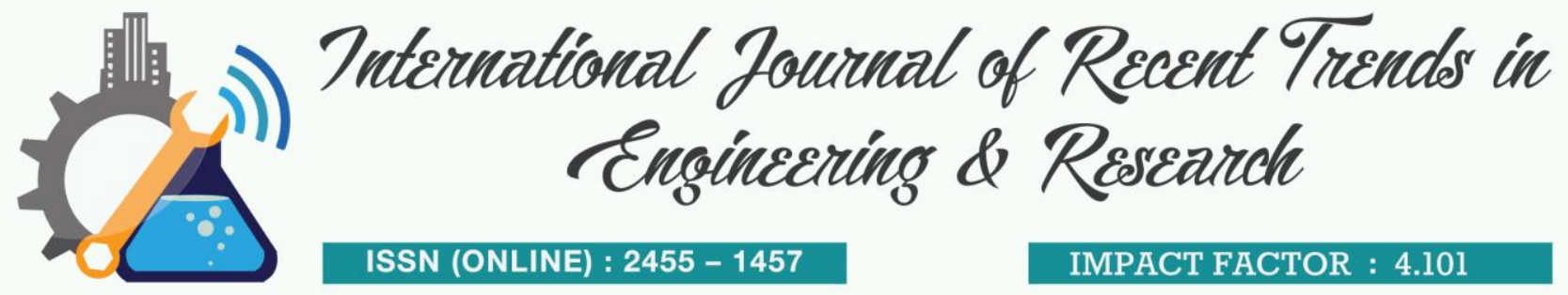

\title{
Haversine Method in Looking for the Nearest Masjid
}

\author{
Subhan Hartanto ${ }^{1}$, Mhd. Furqan ${ }^{2}$, Andysah Putera Utama Siahaan ${ }^{3}$, Wirda Fitriani ${ }^{4}$ \\ ${ }^{1,3,4}$ Faculty of Computer Science, Universitas Pembangunan Panca Budi, Medan, Indonesia \\ ${ }^{2}$ Department of Computer Science, UIN Sumatera Utara, Medan, Indonesia \\ ${ }^{3}$ Ph.D. Student of School of Computer and Communication Engineering, \\ Universiti Malaysia Perlis, Kangar, Malaysia
}

\begin{abstract}
Determination of the nearest distance is often a problem to get to somewhere. This happens when Muslims want to find masjid when they want to worship. As the time of worship is nearing its end, they are very confused to find the nearest masjid from their location. In manual calculations, this is very difficult to do where several masjids become an option. The Haversine method is an excellent method for finding the nearest place based on the coordinates of the earth. This method will calculate the distance with the Euclidean distance algorithm based on the latitude and longitude of the earth. These values are obtained by using Google Maps. On Google Maps, certain points have specific longitude and latitude. It is very helpful in determining the points of the masjid's location. This study performs these calculations to get the closest distance from the search. It is done based on a straight line between the user's position and the target. The weakness of this algorithm, it can not know the obstacles that exist into the nearest masjid. This algorithm only calculates the distance based on a straight line. However, it is helpful for people to find the nearest masjid from their position.
\end{abstract}

Keywords - Shortest Path, Haversine, Masjid

\section{INTRODUCTION}

One of the requirements for Muslims in each region including the village is the masjid as a place of worship [4]. Each city has some masjids in different locations. The number of adherents of Islam will increase along with the coming of converts from various directions. The various locations and positions of the masjid cause the confused people to have to choose in the masjid where he will perform the worship, even more, the people do not know exactly the location of the masjid is located. It confuses Muslims, especially the immigrants when looking for masjid to worship by the closest location where the community is located. Each masjid will have a specific location and information, especially in information at the time of Ramadhan and Syawal. The information held by each masjid will always be different. From these differences, the density of activity and the lack of information about the masjid became a factor for the election of Muslims, especially Muslim immigrants to worship. The rapidly developing technology should be able to assist Muslims in solving the problem. The closest route is always used regarding time optimization [1][2][7]. Location Based Service is a Google Maps service to provide information based on where the user is located and the route where the desired location, while the Haversine Formula to calculate the distance and find the closest distance between the user application and the intended masjid. Expected after getting information and location, the number of Muslims who come to the masjid will always increase day by day.

\subsection{Masjid}

\section{THEORIES}

Masjid (مسجد) is a place used for prostration. Then the meaning extends into a special building that is used as a place for gathering people to pray in congregation. Az-Zarkasyi said, "When prostration is the noblest deed in prayer, because of the proximity of God's servants to Him in prostration, the place 
of prayer is taken from the word prostration (masjad = place of prostration). They do not call it or anything else. Then the sound of "masjad" changed into a masjid, which in term means a special building provided for the five-time prayers. In contrast to places used for 'Id prayers or the like (i.e. Istisqa') called 'المصلى' (musholla = Islamic Prayer Room). The laws for the masjid can not be applied to the musholla [4].

\subsection{Google Maps}

Google Maps is a free map provided by Google companies that can be accessed through the site http://maps.google.com. Geographic information and city planning can be viewed in detail when the map opens. This service has an interactive interface. Map position can be shifted and enlarged as desired. Moreover now Google Maps already has Street View. It is a virtual reality for the streets of this earth. Also, Google Maps also offers maps that are twisted around the world, and offer travel routes.

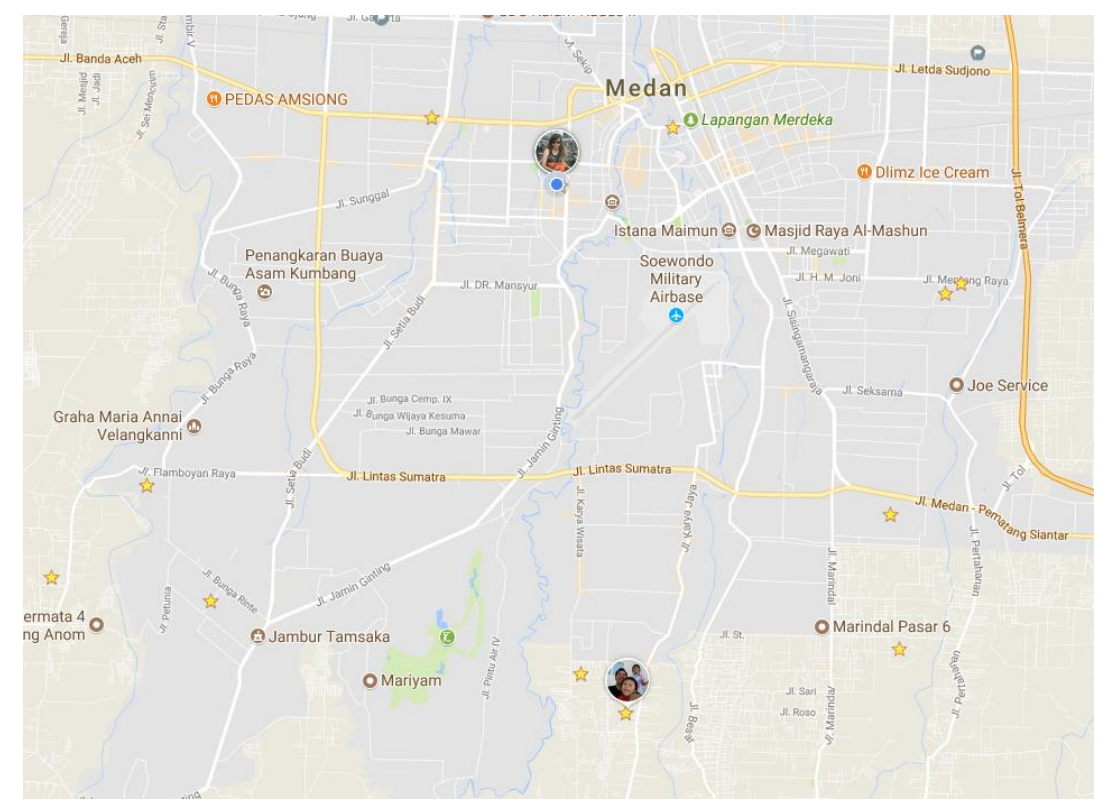

Figure 1. Google Maps

In Figure 1, this is an example snippet of Google Maps. Google Maps at this time already has location sharing feature. It aims to see the locations of friends who have been registered. By enabling location sharing, one can monitor other user activity for 24 hours. Another function of this facility is to provide an interconnected family. It is to prevent things that are not desirable.

\subsection{Haversine}

The Haversine theorem is used to calculate the lengths of two points on the surface of the earth based on latitude and longitude. Four variables must be prepared to calculate the two distances. The Haversine formula is an important equation of navigation, providing a large circular spacing between two points on the surface of the sphere based on longitude and latitude [5][6]. It is a method of knowing the distance between two points by taking into account that the earth is not a plane but is a plane of a degree of curvature and has a radius of $6,367.45 \mathrm{~km}$. 


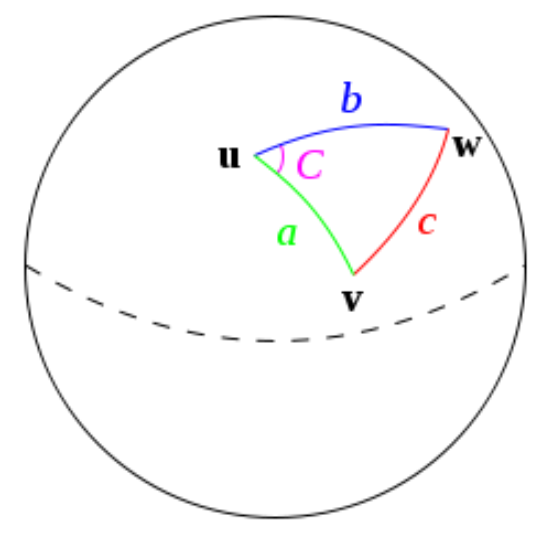

Figure 2. Spherical triangle solved by the law of haversines

Figure 2 describes how the Haversine method works. The working of this algorithm is to establish a direct distance between points that can be stretched in a triangular form where $a, b$, and $c$ are the distances to be calculated. The following formulas are the way to perform Haversine algorithm:

$$
\operatorname{hav}\left(\frac{d}{r}\right)=\operatorname{hav}\left(\varphi_{2}-\varphi_{1}\right)+\cos \left(\varphi_{1}\right) \cos \left(\varphi_{2}\right) \operatorname{hav}\left(\lambda_{2}-\lambda_{1}\right)
$$

Where:

hav : haversine function:

d : distance between the two points (along a great circle of the sphere; see spherical distance), $\mathrm{r} \quad: \quad$ radius of the sphere, $\varphi 1, \varphi 2$ : $\quad$ latitude of point 1 and latitude of point 2 , in radians $\lambda 1, \lambda 2: \quad$ longitude of point 1 and longitude of point 2 , in radians

On the left side of the equals sign $\mathrm{d} / \mathrm{r}$ is the central angle, assuming angles are measured in radians (note that $\varphi$ and $\lambda$; can be converted from radians to degrees by multiplying by $180 / \pi$ as usual) [3]. Solve for $\mathrm{d}$ by applying the inverse haversine (if available) or by using the arcsine (inverse sine) function:

$$
d=2 \mathrm{r} \cdot \arcsin \left(\sqrt{\sin ^{2}\left(\frac{\Delta \text { latt }}{2}\right)+\cos \left(\text { latt 1) } \cos (\text { latt } 2) \sin ^{2}\right.}\left(\frac{\Delta \text { long }}{2}\right)\right)
$$

Below is a Delphi program to find the value of Haversine:

program Haversine;

uses Math;

function HaversineDist(th1, ph1, th2, ph2:double):double; const diameter $=2 * 6372.8$;

var dx, dy, dz:double;

begin

ph1 := degtorad(ph1 - ph2);

th1 := degtorad(th1);

th2 := degtorad(th2); 


$$
\begin{array}{ll}
\mathrm{dz} & :=\sin (\mathrm{th} 1)-\sin (\mathrm{th} 2) \\
\mathrm{dx} & :=\cos (\mathrm{ph} 1) * \cos (\mathrm{th} 1)-\cos (\mathrm{th} 2) \\
\mathrm{dy} & :=\sin (\mathrm{ph} 1) * \cos (\mathrm{th} 1) \\
\text { Result }:=\arcsin (\operatorname{sqrt}(\operatorname{sqr}(\mathrm{dx})+\operatorname{sqr}(\mathrm{dy})+\operatorname{sqr}(\mathrm{dz})) / 2) * \text { diameter; }
\end{array}
$$

end;

begin

Writeln('Haversine distance: ', HaversineDist(36.12, -86.67, 33.94, -118.4):7:2, ' km.'); end.

\subsection{Masjid Location}

\section{METHODOLOGY}

In this study, the city of Medan is taken as a test of the existence of the masjid. The author provides five addresses of masjids that have different locations. The following table is the longitude and latitude data of the masjids.

Table 1. Masjid location

\begin{tabular}{|c|l|c|c|}
\hline No. & \multicolumn{1}{|c|}{ Name } & Lattitude & Longitude \\
\hline 1 & Masjid Agung & 3,581252 & 98,671986 \\
\hline 2 & Masjid Raya & 3,575129 & 98,687373 \\
\hline 3 & Masjid Al-Jihad & 3,577360 & 98,658837 \\
\hline 4 & $\begin{array}{l}\text { Masjid Aceh } \\
\text { Sepakat }\end{array}$ & 3,585226 & 98,662039 \\
\hline 5 & Masjid Al-Ikhlas & 3,595719 & 98,680790 \\
\hline
\end{tabular}

\section{EVALUATION}

In this test, the author puts the position of someone who is in Lattitude $=3.5814159$ and Longitude $=$ 98.6602269. The calculations below will show which of the five masjids is the highest priority.

\section{Masjid Agung}

$$
\begin{array}{ll}
\text { SLa } & =3.5814159 \\
\text { SLo } & =98.6602269 \\
\text { TLa } & =3.581252 \\
\text { TLo } & =98.671986 \\
\text { Sin SLa } & =\operatorname{Sin} 3.5814159 \\
& =0.062466803 \\
\text { Sin TLa } & =\operatorname{Sin} 3.581252 \\
& =0.062463948 \\
\text { SS } & =\operatorname{Sin~SLa~} * \operatorname{Sin} \mathrm{TLa} \\
& =0.062466803 * 0.062463948 \\
& =0.003901923
\end{array}
$$

Cos SLa $=$ Cos 3.5814159

$=0.998047042$ 


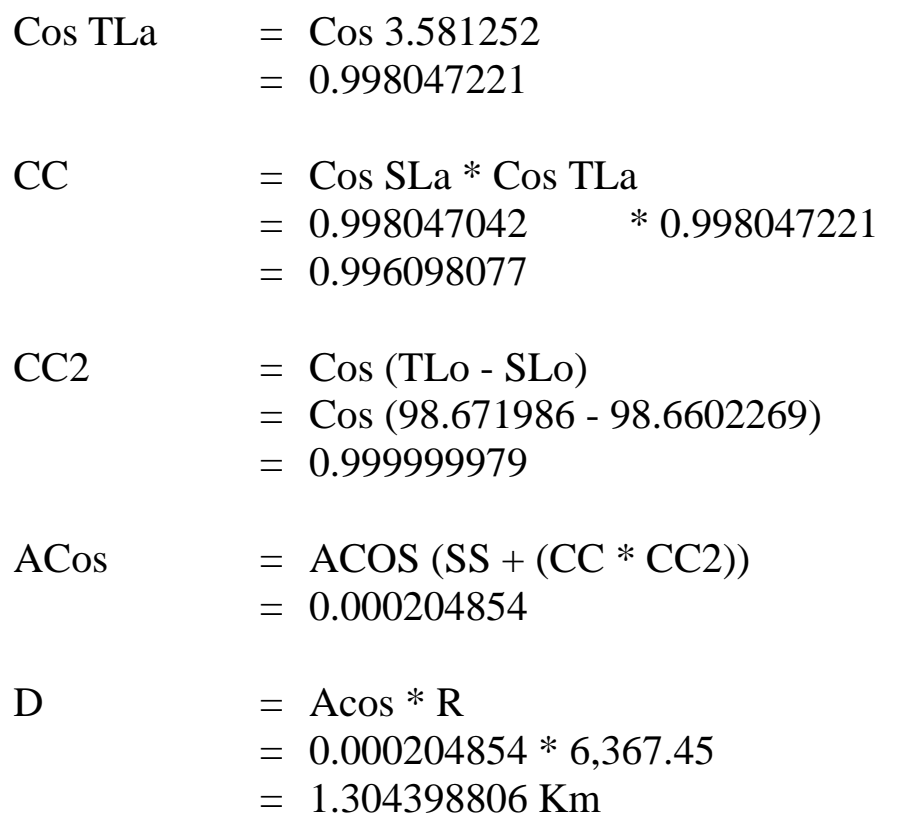

\section{Masjid Raya}

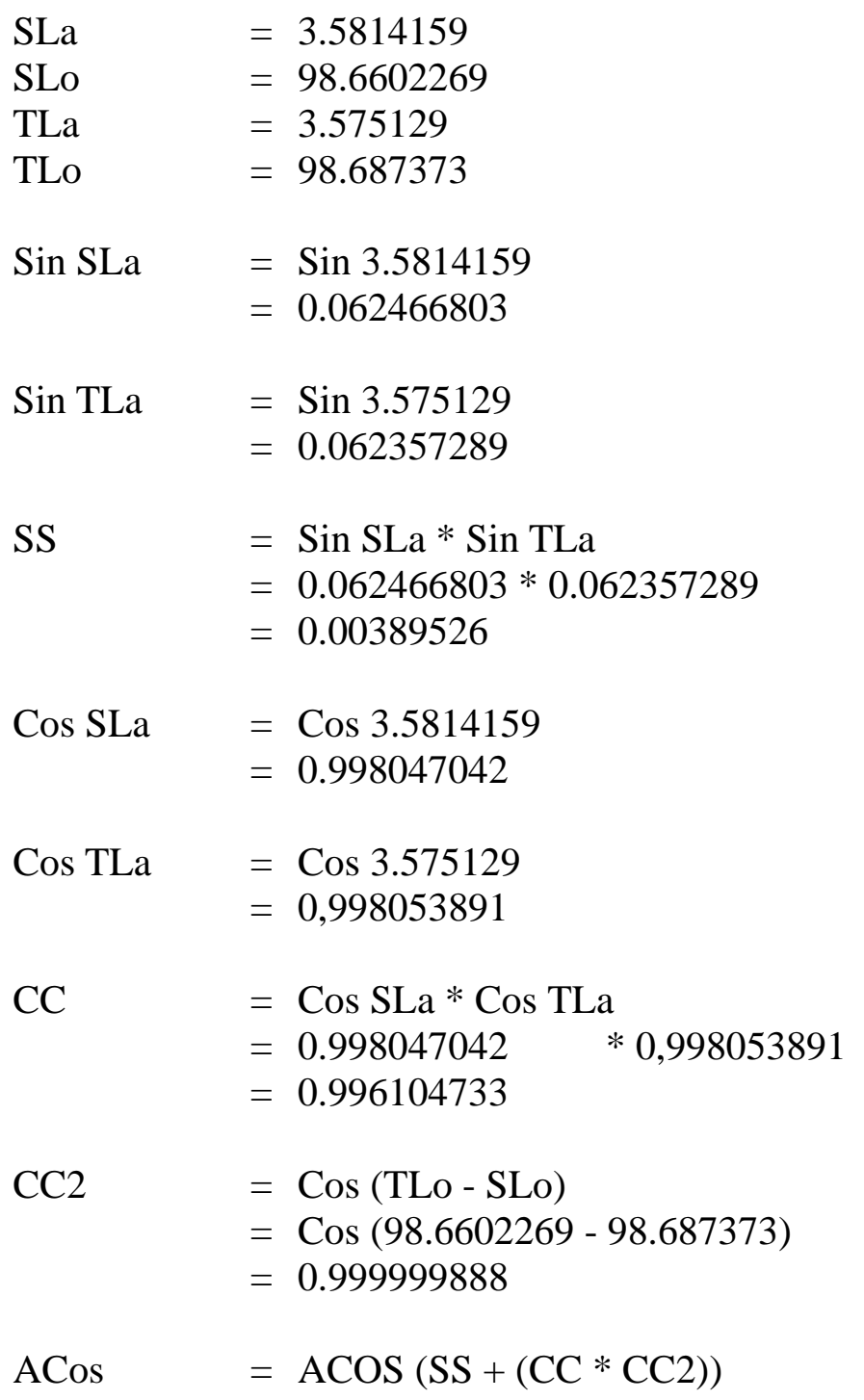




$$
=0.000485429
$$

$$
\begin{aligned}
\mathrm{D} & =\mathrm{A} \cos * \mathrm{R} \\
& =0.000485429 * 6,367.45 \\
& =3.09094607 \mathrm{Km}
\end{aligned}
$$

\section{Masjid Al-Jihad}

$$
\begin{aligned}
& \text { SLa } \quad=3.5814159 \\
& \text { SLo } \quad=98.6602269 \\
& \mathrm{TLa} \quad=3.577360 \\
& \text { TLO }=98.658837 \\
& \text { Sin } \mathrm{SLa}=\operatorname{Sin} 3.5814159 \\
& =0.062466803 \\
& \text { Sin TLa }=\operatorname{Sin} 3.577360 \\
& =0.062396152 \\
& \text { SS } \quad=\text { Sin SLa } * \text { Sin TLa } \\
& =0.062466803 * 0.062396152 \\
& =0.003897688 \\
& =0.998047042 \\
& =0.998047042 \quad * 0.998051462 \\
& =0.996102309 \\
& \mathrm{CC} 2=\operatorname{Cos}(\mathrm{TLo}-\mathrm{SLo}) \\
& =\operatorname{Cos}(98,658837-98.6602269) \\
& =1
\end{aligned}
$$

\section{Masjid Aceh Sepakat}

$\begin{aligned} \text { SLa } & =3.5814159 \\ \text { SLo } & =98.6602269 \\ \text { TLa } & =3.585226 \\ \text { TLo } & =98.662039\end{aligned}$




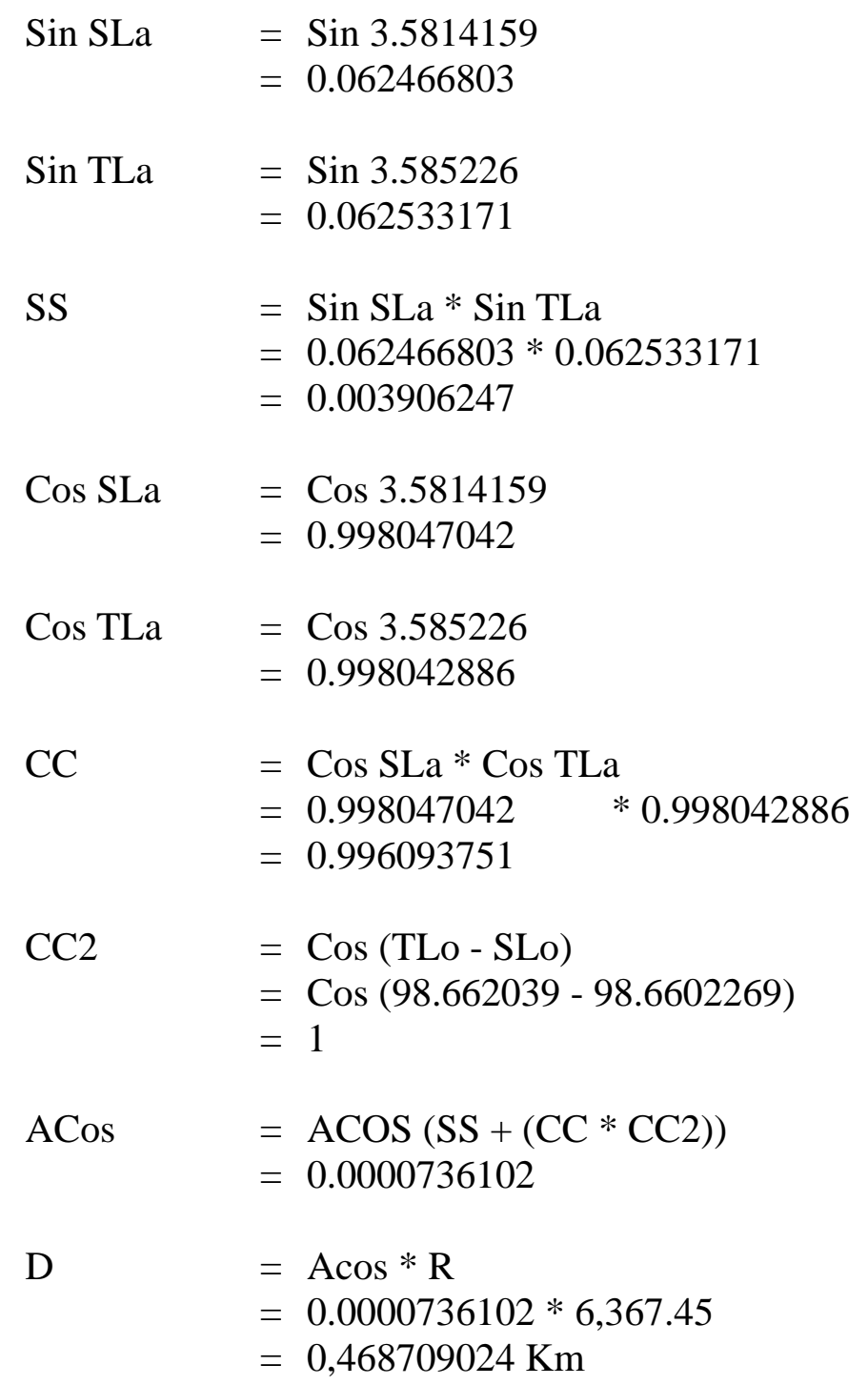

\section{Masjid Al-Ikhlas}

$\begin{array}{ll}\text { SLa } & =3.5814159 \\ \text { SLo } & =98.6602269 \\ \text { TLa } & =3.595719 \\ \text { TLo } & =98.680790 \\ \text { Sin SLa } & =\operatorname{Sin} 3.5814159 \\ & =0.062466803 \\ \text { Sin TLa } & =\operatorname{Sin} 3.595719 \\ & =0.062715949 \\ \text { SS } & =\operatorname{Sin~SLa~} * \operatorname{Sin} \mathrm{TLa} \\ & =0.062466803 * 0.062715949 \\ & =0.003917665\end{array}$




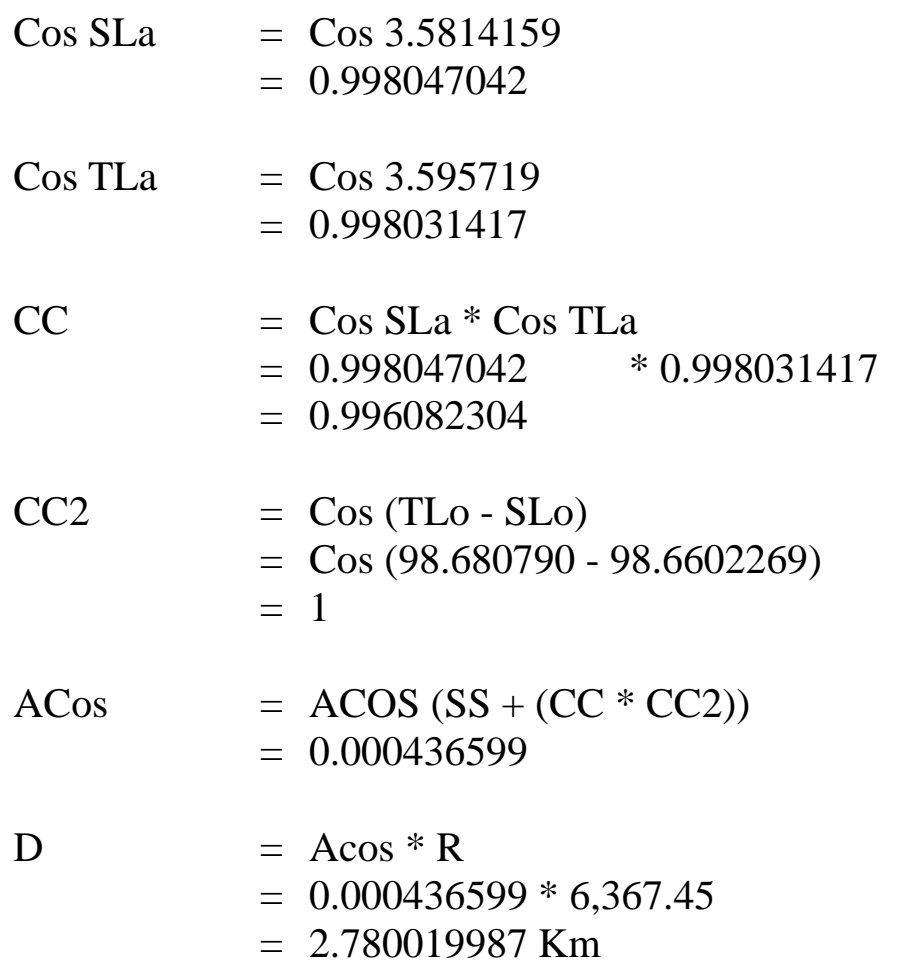

Table 2. Haversine result

\begin{tabular}{|c|l|r|}
\hline No. & \multicolumn{1}{|c|}{ Name } & Distance $(\mathbf{k m})$ \\
\hline 1 & Masjid Agung & 1,304398806 \\
\hline 2 & Masjid Raya & 3,09094607 \\
\hline 3 & Masjid Al-Jihad & 0,476378389 \\
\hline 4 & $\begin{array}{l}\text { Masjid Aceh } \\
\text { Sepakat }\end{array}$ & 0,468709024 \\
\hline 5 & Masjid Al-Ikhlas & 2,780019987 \\
\hline
\end{tabular}

Table 2 is the Haversine calculation result. It explains that the Masjid of Aceh Sepakat is the closest to the user's position. So the first goal of the congregation can be directed to the masjid.

\section{Conclusion}

The application of the Haversine method is very well applied to gadgets since the Google Maps service, especially on smartphones. Once this app is on their gadget, a Haversine search is useful for locating nearby masjids, especially when Muslims are almost out of prayer time. The congregation can decide which masjid they will go to. This method will determine which masjid is closest to them. However, the weakness of this system, Haversine's method never knows the obstacles in pursuing the goal. It is best if the method is combined with a database that records the location state of a place so that the search will be optimal.

\section{REFERENCES}

[1] H. J. Cho and C. L. Lan, "Hybrid Shortest Path Algorithm For Vehicle Navigation," Journals Springer Science, vol. 10, no. 49, pp. 234-247, 2008.

[2] F. Lam and A. Newman, "Travelling Salesman Path Problems," Journal Math Program, vol. 10, no. 113, pp. 39-59, 2005.

[3] Wikipedia, "Haversine Formula," Wikipedia, [Online]. Available: https://en.wikipedia.org/wiki/Haversine_formula. [Accessed 20 August 2017]. 
[4] S. S. b. A. b. W. al-Qahthani, "Pengertian Masjid," Media Islam Salafiyyah, Ahlussunnah wal Jama'ah, 18 September 2009. [Online]. Available: https://almanhaj.or.id/2524-pengertian-masjid.html. [Accessed 20 August 2017].

[5] N. R.Chopde and M. K. Nichat, "Landmark Based Shortest Path Detection by Using A* and Haversine Formula," International Journal of Innovative Research in Computer and Communication Engineering, vol. 1, no. 2, pp. 298302, 2013.

[6] G. L. and V. K. B. P., "Indoor Wireless Localization using Haversine Formula," International Advanced Research Journal in Science, Engineering and Technology, vol. 2, no. 7, pp. 59-63, 2015.

[7] A. P. U. Siahaan, "Adjustable Knapsack in Travelling Salesman Problem Using Genetic Process," International Journal Of Science \& Technoledge, vol. 4, no. 9, pp. 46-55, 2016. 